\title{
Dry Mass Increment, Foliar Nutrientes and Soybean Yield as Affected by Aminoacid Application
}

\author{
Walquíria F. Teixeira ${ }^{1}$, Evandro B. Fagan ${ }^{2}$, Luís H. Soares ${ }^{2}$, Klaus Reichardt ${ }^{3}$, Leidyanne G. Silva ${ }^{2}$ \\ \& Durval Dourado-Neto ${ }^{1}$ \\ 1 “Luiz de Queiroz" College of Agriculture, University of São Paulo, Piracicaba, SP, Brazil \\ ${ }^{2}$ University Center of Patos de Minas, Patos de Minas, MG, Brazil \\ ${ }^{3}$ Center for Nuclear Energy in Agriculture, University of São Paulo, Piracicaba, SP, Brazil \\ Correspondence: Walquíria F. Teixeira, Crop Science Department, "Luiz de Queiroz" College of Agriculture, \\ University of Sao Paulo, 13418-970, Piracicaba, SP, Brazil. Tel: 55-19-3429-4148. E-mail: \\ walquiria_bio@hotmail.com
}

Received: August 20, 2019

doi:10.5539/jas.v11n18p230

\author{
Accepted: October 11, $2019 \quad$ Online Published: November 15, 2019 \\ URL: https://doi.org/10.5539/jas.v11n18p230
}

\begin{abstract}
Due to the importance of soybeans worldwide, there is a constant search for products or management systems that aim to increase the productivity of this crop. In this sense, some products that have amino acids in their composition have been used, however, there is still a lack of studies that aim to show the isolated effect of amino acids on growth parameters. Therefore, the present study aimed to evaluate the effect of the application of amino acids in the treatment of seeds and of the leaf in the soybean crop. Experiments were carried out in a greenhouse and in the field with the application of glutamate, phenylalanine, cysteine, glycine as a seed treatment (ST) and also as foliar application (FA) at the $\mathrm{V}_{4}$ growth stage. The dry mass accumulation of root, stem, leaves, total and yield of a soybean crop were evaluated. In addition, leaf element concentration in leaves was also evaluated. The use of phenylalanine in ST promoted the best results on stem mass, leaves, pods and total dry mass, with an increase of up to $152 \%$, as compared to control. This same treatment led to higher productivity, with a $46 \%$ increase in relation to the control. In relation to foliar concentration of elements, the most effective application is the one that is carried out in both modes of application (ST and FA), mainly with glutamate and glycine. Therefore, the application of amino acids, especially in seed treatment promotes the greater accumulation of dry mass and productivity in soybean plants.
\end{abstract}

Keywords: glutamate, cysteine, phenylalanine, glycine, seed yield

\section{Introduction}

Amino acids are organic molecules formed by carbon, hydrogen, oxygen and nitrogen, and all of them have a carboxyl group $(\mathrm{COOH})$ and an amine group $\left(\mathrm{NH}_{2}\right)$ attached to a carbon atom which has attached another hydrogen atom and a $(\mathrm{R})$ radical. The $(\mathrm{R})$ radical represents an organic radical, different in each amino acid molecule found in living matter. Each variation in the amino acid number or sequence produces a different protein and thus, there is a wide variety of proteins. In recent years, a number of amino acid transporters have been discovered in plants, among them LHT1 (Lysine Histidine Transporter 1), AAP1 and AAP5 (Amino Acid Permease 1 and 5). These are present mainly in the roots, but according to Weiland et al. (2015), they can also be found in leaves. This information shows that plants can absorb soil amino acids, as already confirmed by Hirner et al. (2006) and Lee et al. (2007), and indicate that the absorption could possibly happen by the leaf.

In contrast, a large volume of work has shown the effect of amino acids when applied to plants. These can be used as stress-reducing agents, nitrogen source and hormone precursors (Zhao, 2010; DeLille et al., 2011; Maeda \& Dudareva, 2012). In addition, more recently amino acids have been proposed as plant flags after the identification of glutamate receptors (GRLs), but which are also capable of binding to other amino acids. When these receptors are activated, several physiological processes are triggered, such as nitrogen uptake regulation (Miller et al., 2007), root development (Walch-Liu \& Forde, 2007; Weiland et al., 2015) and antioxidant metabolism (Hildebrandt et al., 2015, Weiland et al., 2015). 
These effects together can provide greater accumulation of dry matter mass and changes in the concentration of nutrients in the leaves, which can have repercussions on productivity increases of the soybean crop.

Germination of lupine seeds in vitro in a solution containing $35 \mathrm{mM}$ asparagine showed an increase in starch content and a reduction in the concentration of soluble sugars (Borek et al., 2013). However, studies exploring these effects in soybeans are scarse. In addition, most studies have used mixtures of amino acids or formulated products without the proper characterization of amino acids, which makes it difficult to understand the effect that each single amino acid can cause in plants.

The objective of the present work was, therefore, to evaluate the effect of the application of glutamate, cysteine, phenylalanine and glycine (via seeds, leaves or both modes of application) on the accumulation of dry matter mass and nutrients, and on soybean seed yield.

\section{Method}

\subsection{Greenhouse Experiment}

This experimente was carried out in Piracicaba, SP, Brazil $\left(22^{\circ} 41^{\prime} \mathrm{S}, 47^{\circ} 38^{\prime} \mathrm{W}\right.$ and $546 \mathrm{~m}$ asl.), using pots of 11 $\mathrm{dm}^{3}$ capacity, filled with washed sand and installed in a plant growth greenhouse. Ten soybean seeds (Glycine $\max$ L. Merrill), cultivated variety NS 7901 RR were sown in each pot and, after emergence, thinning was done, leaving only three plants per pot.

The experiment was carried out using a randomized block design, consisting of the application of amino acids as seed treatment (ST) and/or foliar application (FA) at $\mathrm{V}_{4}$ stage (four nodes on the main stem, 20 DAS), using eight blocks per treatment (Table 1). Before application of the treatments, all the seeds were treated with fungicide and insecticide [fipronil $\left(250 \mathrm{~g} \mathrm{~L}^{-1}\right)+$ methyl thiophanate $\left(225 \mathrm{~g} \mathrm{~L}^{-1}\right)+$ pyraclostrobin $\left(25 \mathrm{~g} \mathrm{~L}^{-1}\right)$ ] at the rate of $1 \mathrm{~mL} \mathrm{~kg}^{-1}$ of seeds.

Table 1. Concentration of different amino acids, and time of application, where (ST) were the applications performed only on seeds, (FA) foliar application, and both ST and FA

\begin{tabular}{|c|c|c|c|c|}
\hline \multirow[b]{2}{*}{ Amino acids ${ }^{1}$} & \multicolumn{4}{|c|}{ Moment of application } \\
\hline & $\begin{array}{l}\text { Only seed treatment (ST) } \\
\left(\mathrm{mg} \mathrm{kg}^{-1}[\text { seeds }]\right)\end{array}$ & $\begin{array}{l}\text { Only foliar application } \\
\text { (FA) at } \mathrm{V}_{4}\left(\mathrm{mg} \mathrm{ha}^{-1}\right)\end{array}$ & Both ST + FA & \\
\hline Control & 0 & 0 & 0 & 0 \\
\hline Glutamate (Glu) & 12 & 123 & 12 & 123 \\
\hline Cysteine (Cys) & 12 & 123 & 12 & 123 \\
\hline Phenylalanine (Phe) & 3 & 30 & 3 & 30 \\
\hline Glycine (Gly) & 9 & 92 & 9 & 92 \\
\hline $\mathrm{Glu}+\mathrm{Cys}+\mathrm{Phe}+\mathrm{Gly}$ & $12+12+3+9$ & $123+123+30+92$ & $12+12+3+9$ & $123+123+30+92$ \\
\hline
\end{tabular}

Note. ${ }^{1}$ The sources used equivalent to the pure amino acids, with optical isomerism levogyrous (L-amino acid).

The pots were irrigated daily according to the water requirement $(400 \mathrm{~mL}$ per pot), and a weekly application of nutrient solution proposed by Johnson et al. (1957) was performed during the experiment.

\subsection{Field Experiment}

This experiment was conducted in Patos de Minas (MG), Brazil $\left(18^{\circ} 34^{\prime} \mathrm{S}, 46^{\circ} 31^{\prime} \mathrm{W}\right.$ and $815 \mathrm{~m}$ asl.), in the 2014/2015 season. Before sowing, soil samples were collected from the area where the experiment was installed. The chemical analysis of the soil is presented in Table 2. As fertilization, $450 \mathrm{~kg} \mathrm{ha}^{-1}$ of formulation 08:30:10+ $3.26 \%$ of $\mathrm{Ca}+4.25 \%$ of $\mathrm{S}+0.2 \%$ of $\mathrm{B}+0.2 \% \mathrm{Zn}$ were used. Before the installation of this experiment, the area was cultivated with maize for silage. 
Table 2. Soil analysis $(0-20 \mathrm{~cm})$ of the field experiment

\begin{tabular}{|c|c|c|c|c|c|c|c|}
\hline $\mathrm{pH}$ & P-Me1 & P-rem & $\mathrm{K}^{+}$ & $\mathrm{Ca}^{2+}$ & $\mathrm{Mg}^{2+}$ & $\mathrm{Al}^{3+}$ & $\mathrm{H}+\mathrm{Al}$ \\
\hline in water & \multicolumn{3}{|c|}{ 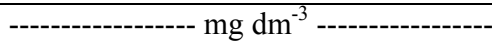 } & \multicolumn{4}{|c|}{---------'----- $\mathrm{cmol}_{\mathrm{c}} \mathrm{dm}^{-3}$} \\
\hline 5.60 & 10.23 & 4.94 & 85.70 & 2.94 & 0.56 & 0.02 & 1.30 \\
\hline SB & $\mathrm{t}$ & \multicolumn{2}{|c|}{$\mathrm{T}$} & $\mathrm{V}$ & $\mathrm{m}$ & & $\mathrm{OM}$ \\
\hline \multicolumn{4}{|c|}{ 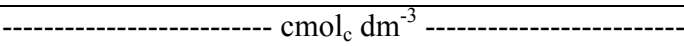 } & ---- & $\%$ & - & \multirow{2}{*}{$\begin{array}{l}\text { dag kg-1 } \\
3.12\end{array}$} \\
\hline 3.72 & 3.74 & & & 74.11 & 0.53 & & \\
\hline
\end{tabular}

Note. P-Mel and $\mathrm{K}^{+}$: Mehich-1 extractor; $\mathrm{Ca}^{+}, \mathrm{Mg}^{+}$and $\mathrm{Al}^{+}: \mathrm{KCl} 1 \mathrm{~mol} \mathrm{~L}{ }^{-1}$ extractor; P-rem: Remaining phosphorus-phosphorus concentration of the equilibrium solution after stirring 1 hour with $10 \mathrm{mmol} \mathrm{L}^{-1} \mathrm{CaCl}_{2}$ solution containing $60 \mathrm{~g}$ of $\mathrm{P}(1: 10)$.

Weed management was performed using glyphosate $\left(480 \mathrm{~g} \mathrm{~L}^{-1}\right)$ at the rate of $2 \mathrm{~L} \mathrm{ha}^{-1}$ at 14 and 35 days after sowing (DAS). For pest management, the application of acetamipride $\left(100 \mathrm{~g} \mathrm{~L}^{-1}\right)+$ alpha-cypermethrin $(200 \mathrm{~g}$ $\left.\mathrm{L}^{-1}\right)$ at the rate of $250 \mathrm{~mL} \mathrm{ha}^{-1}$ and chlorfenapyr $\left(240 \mathrm{~g} \mathrm{~L}^{-1}\right)$ at the rate of $500 \mathrm{~mL} \mathrm{ha}^{-1}$ at $84 \mathrm{DAS}$. Diseases control was performed with pyraclostrobin $\left(133 \mathrm{~g} \mathrm{~L}^{-1}\right)+$ epoxiconazole $\left(50 \mathrm{~g} \mathrm{~L}^{-1}\right)$ at the rate of $600 \mathrm{~mL} \mathrm{ha}^{-1}$ at 54 DAS and fluxapyroxad $\left(167 \mathrm{~g} \mathrm{~L}^{-1}\right)+$ pyraclostrobin $\left(333 \mathrm{~g} \mathrm{~L}^{-1}\right)$, at the rate of $300 \mathrm{~mL} \mathrm{ha}^{-1}$ at 70 and 84 DAS.

The experiment was conducted in a randomized block design, consisting of the application of amino acids as ST and/or FA, using eight blocks per treatment (Table 1). Before application of the treatments all the seeds were treated with fungicide and insecticide [fipronil $\left(250 \mathrm{~g} \mathrm{~L}^{-1}\right)+$ methyl thiophanate $\left(225 \mathrm{~g} \mathrm{~L}^{-1}\right)+$ pyraclostrobin $(25$ $\left.\left.\mathrm{g} \mathrm{L}^{-1}\right)\right]$ at the rate of $1 \mathrm{~mL} \mathrm{~kg}^{-1}$ of seeds.

Soybean seeds (Glycine $\max$ L. Merrill), cultivated variety NS 7901 RR, were planted with the objective of reaching a harvesting population of 250,000 plants $\mathrm{ha}^{-1}$. Each experimental unit consisted of four lines seven meters long, with $0.45 \mathrm{~m}$ between rows, totaling an area of $12.6 \mathrm{~m}^{2}$. In each plot $0.5 \mathrm{~m}$ was discarded at each end, making the useful area of each plot only the central lines.

Amino acid applications via foliar were performed at $\mathrm{V}_{4}$ growth stage with a $\mathrm{CO}_{2}$ propellant sprayer. The bar used contained four fan-type nozzles, being $2.25 \mathrm{~m}$ long and with a pressure of 2 bar. For all applications, a volume of $200 \mathrm{~L} \mathrm{ha}^{-1}$ syrup was prepared.

\subsection{Measurements}

\subsubsection{Elements Concentrations in Leaves}

The element concentrations in leaves at the $\mathrm{V}_{6}$ stage - six nodes on the main stem, 20 DAS. P, K, Mg, S, Ca, Zn, $\mathrm{Mn}, \mathrm{Fe}$ and $\mathrm{Cu}$ were determined by X-ray fluorescence spectroscopy of dispersive energy (EDXRF). Dried plant material $(1 \mathrm{~g})$ was packed into a polyethylene cup of $20 \mathrm{~mm}$ internal diameter and covered with $6-\mu \mathrm{m}$ thick polypropylene film (Mylar $\left.{ }^{\circledR}\right)$. The samples were irradiated in duplicate for 300 s under vacuum using an energy dispersive X-ray fluorescence spectrometer (Shimadzu EDX-720, Shimadzu, Sao Paulo, SP, Brazil). The element content was calculated using the element concentration and dry mass of leaves.

The quantification of the nitrogen concentration in the leaves was performed by the Kjeldahl method, distilling all the ammonium from the digested leaves in a strongly alkaline medium and retaining the ammonia in a solution of boric acid, which was then titrated with $\mathrm{HCl}(0.01 \mathrm{M})$.

\subsubsection{Dry Matter Mass}

Root, stem, leaf and pod dry mass determinations were performed in the $\mathrm{V}_{6}$ and $\mathrm{R}_{7}$ (beginning maturity) stages (40 and $100 \mathrm{DAS}$ ), in the greenhouse experiment and in the $\mathrm{V}_{6}$ and $\mathrm{R}_{8}$ (full maturity) stages (40 and 110 DAS, respectively), in the field experiment. The analysis was performed by inserting three plants per plot in paper bags, and each fragment was stored separately, drying was performed using the standard forced-air oven drying method at constant temperature of $65^{\circ} \mathrm{C}$, to constant mass.

\subsubsection{Seed Yied}

In the greenhouse experiment the plants were harvested manually considering three plants per replicate. The grains harvested from each plant were weighed on a digital scale with an accuracy of 0.01 grams. The water content of the grains was determined and the productivity was calculated with the water content corrected to $13 \%\left(0.13 \mathrm{~g} \mathrm{~g}^{-1}\right)$. In the greenhouse experiment, the productivity was determined in grams per plant, from three plants per replicate. In the field experiment, the plants were harvested manually considering the two central 
rows, discarding the $0.5 \mathrm{~m}$ at each end. After this, weights and measurements were obtained as described for the other experiments and the productivity was determined per unit area.

\subsubsection{Statistical Analysis}

The data obtained in the two experiments were evaluated for normality and homogeneity using the Shapiro-Wilk and Levene tests, respectively $(\mathrm{p}<0.05)$.

The analysis of variance was performed and, when significant, the Duncan test was applied $(\mathrm{p}<0.05)$. For the two experiments, multivariate analyzes were performed through Principal Component analysis. From the analysis, the eigenvalues (values representative of the retained variability for each new component) and eigenvectors (values representative of the location of the points in the graph) were calculated. By means of these data we determined which variables were more representative in the variability of the data, being able, therefore, to generate a two-dimensional chart of the type byplot.

All analyzes were performed using the statistical software SAS 9.3 (SAS Institute, 2011).

\section{Results}

\subsection{Greenhouse Experiment}

The application of cysteine in ST and glycine applied in both modes ST and FA presented higher root dry mass of plants at the $\mathrm{V}_{6}$ stage (Figure 1A). At this same stage, the application of cysteine and set of amino acids via FA raised the stem dry mass in $82 \%$ (Figure $1 \mathrm{~B}$ ). Amino acid application had no effect on leaf dry mass and total dry mass (Figures $1 \mathrm{C}$ and 1D).

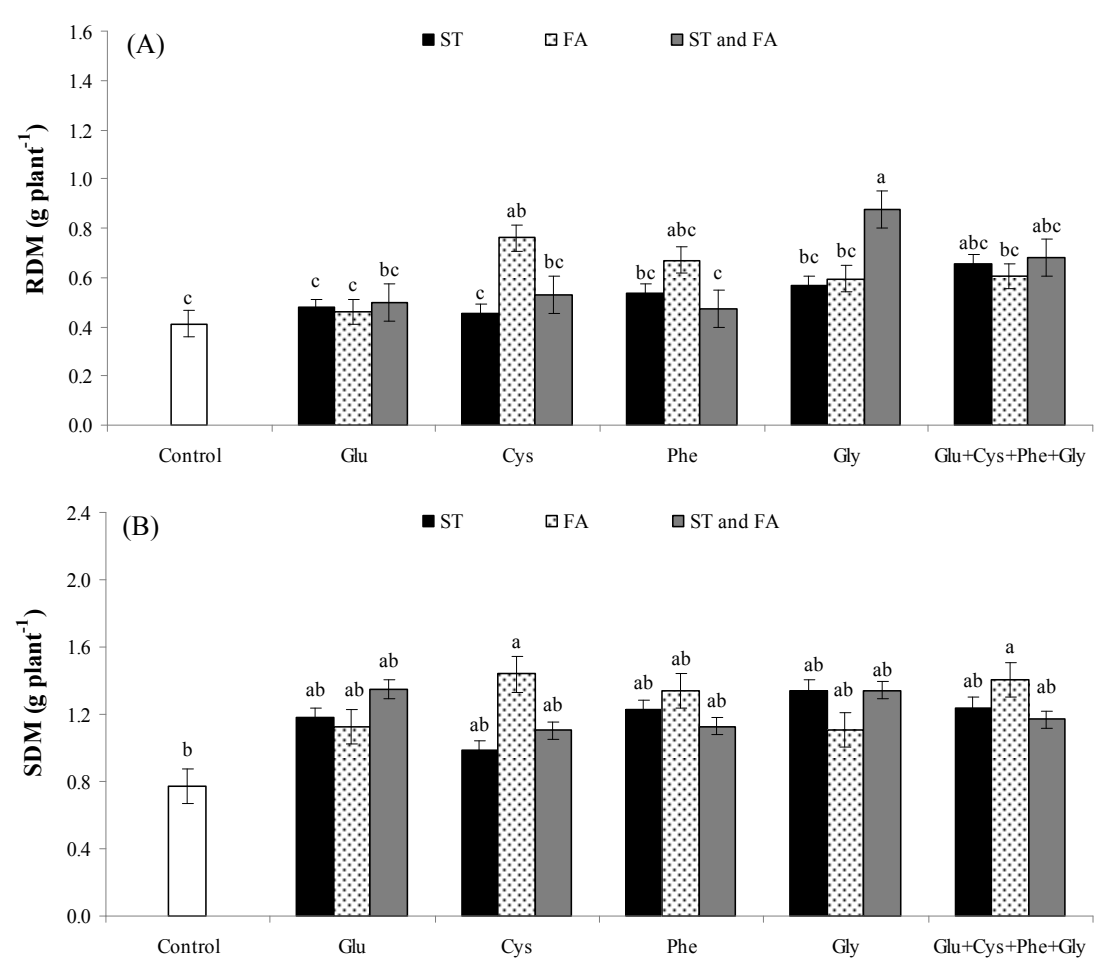




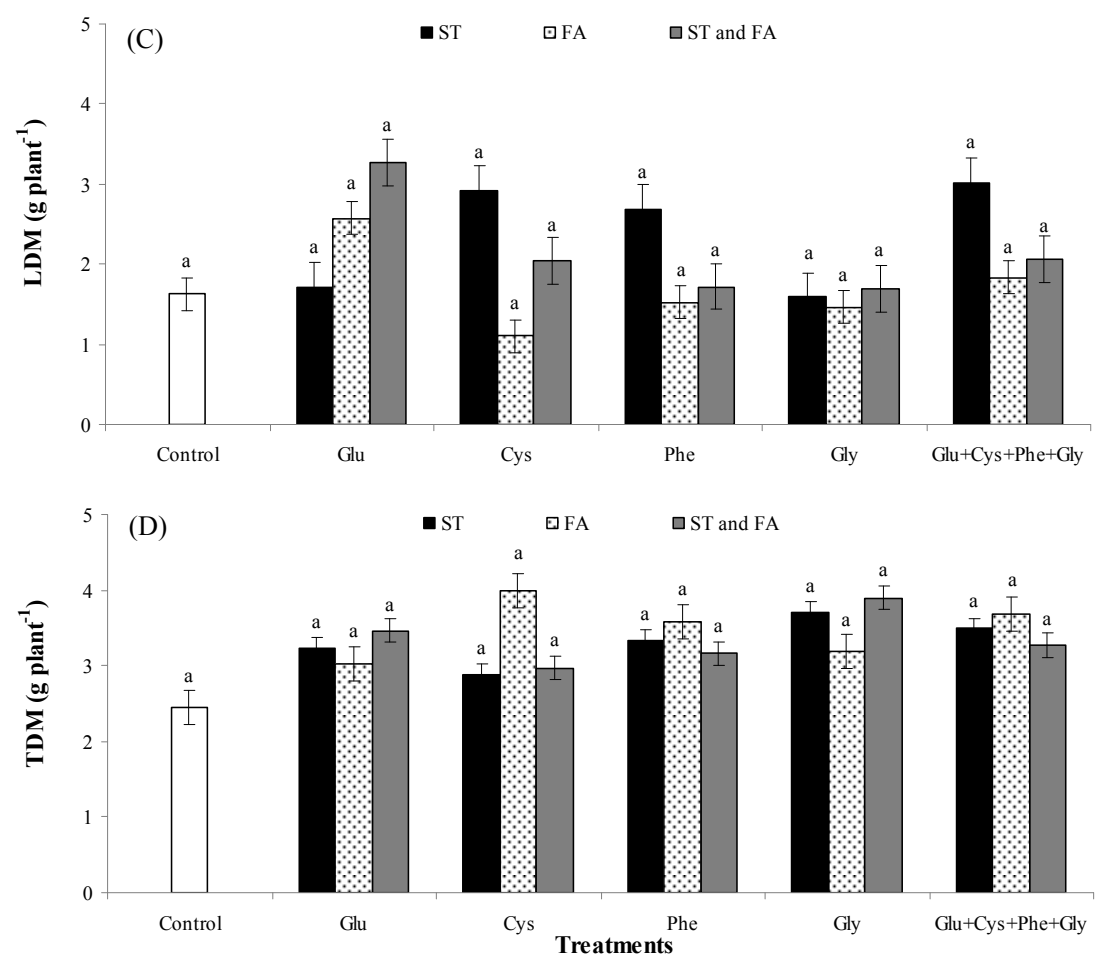

Figure 1. Effects of use of glutamate (Glu), cysteine (Cys), phenylalanine (Phe), glycine (Gly) and all these amino acids in association (Glu + Cys + Phe + Gly), as function of seed treatment (ST) and foliar application (FA), on the root dry mass (RDM, A), stem dry mass (SDM, B), leaf dry mass (LDM, C) and total dry mass (TDM, D) at $\mathrm{V}_{6}$ stage. Greenhouse experiment. Season 2014/2015. Means followed by the same letters do not differ significantly from each other, using the Duncan test $(p>0.05)$

At the $\mathrm{R}_{7}$ stage, the use of glutamate applied in both modes increased the root and stem dry mass (Figures $2 \mathrm{~A}$ and $2 \mathrm{~B}$ ). On the other hand, the application of the set of amino acids raised the leaf and total dry mass (Figures $2 \mathrm{C}$ and $2 \mathrm{D}$ ). There were no significant effects of amino acid application on plant productivity compared to control. Only a difference between the treatments with amino acids was observed, in which the use cysteine as ST increased the soybean seed yield by $30 \%$ in relation to this same treatment as FA (Figure 2E).

The analysis of main components (PC), indicated two variables with the greatest representativeness (Figure 3), seed yield as $\mathrm{PC}_{1}$ and total dry mass at $\mathrm{R}_{7}$ as $\mathrm{PC}_{2}$.

Positive correlations were found between seed yield and TDM, LDM, RDM and SDM at $\mathrm{R}_{7}$ stage, knowing that the increase of these variables promotes the increase in seed yield. According to the analysis, the use of phenylanaline and all these amino acids in association with ST and glutamate applied in both modes increased the seed yield.

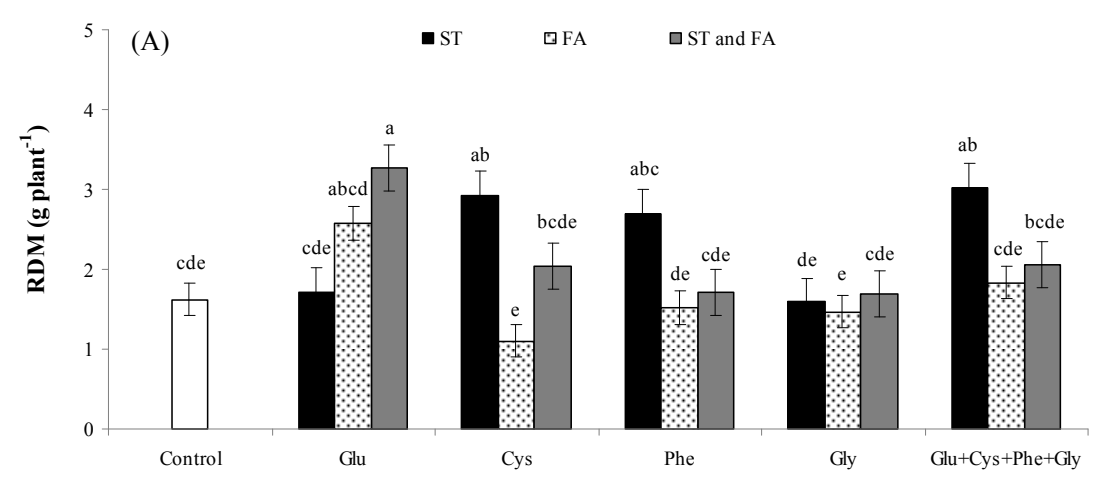



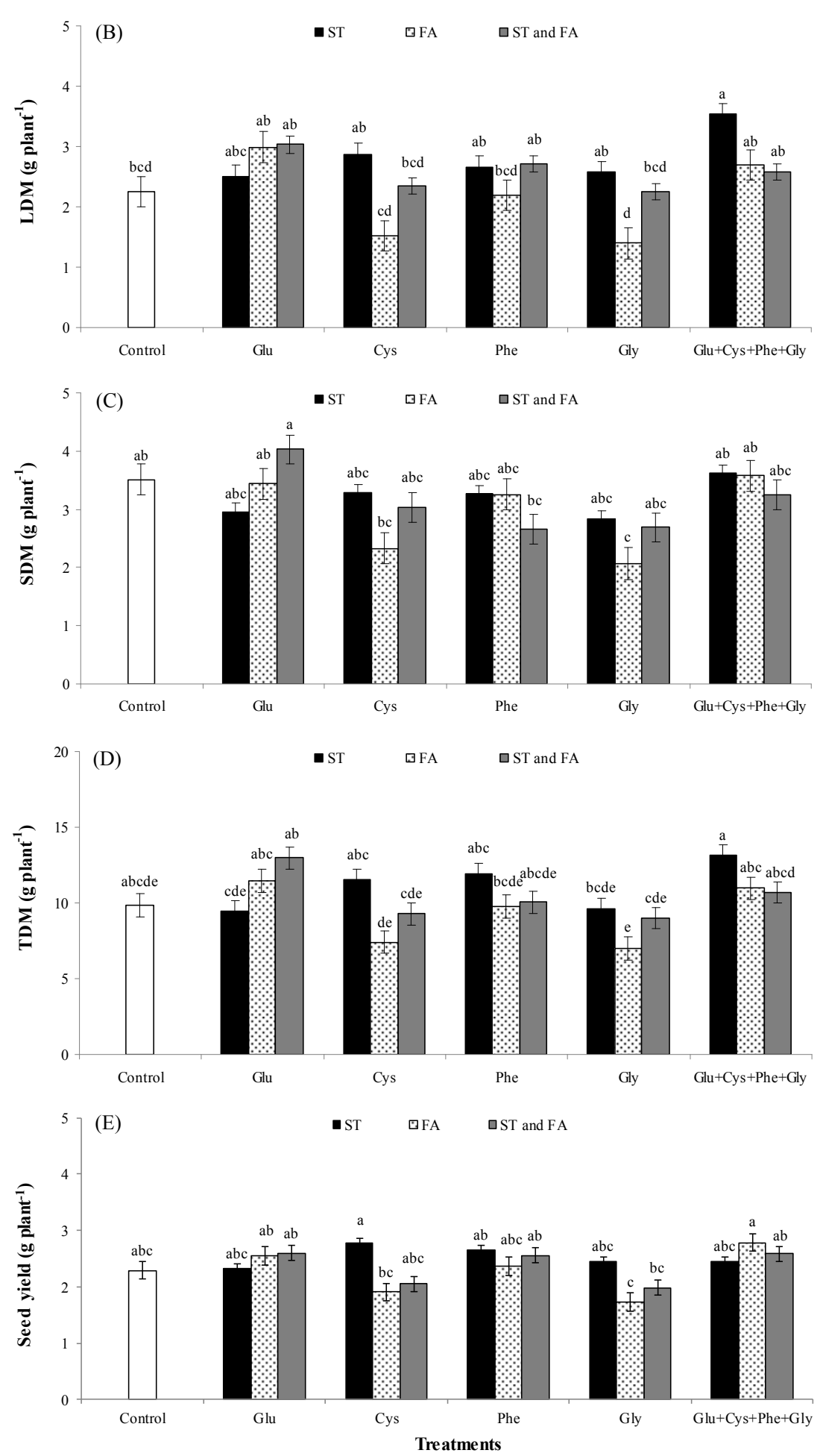

Figure 2. Effects of use of glutamate (Glu), cysteine (Cys), phenylalanine (Phe), glycine (Gly) and all these amino acids in association (Glu + Cys + Phe + Gly), as function of seed treatment (ST) and foliar application (FA), on the root dry mass (RDM, A), leaf dry mass (LDM, B), stem dry mass (SDM, C) and total dry mass (TDM, D), at $\mathrm{R}_{7}$ stage and soybean seed yield (E). Greenhouse experiment. Season 2014/2015. Means followed by the same letters do not differ significantly from each other, using the Duncan $(p>0.05)$ 


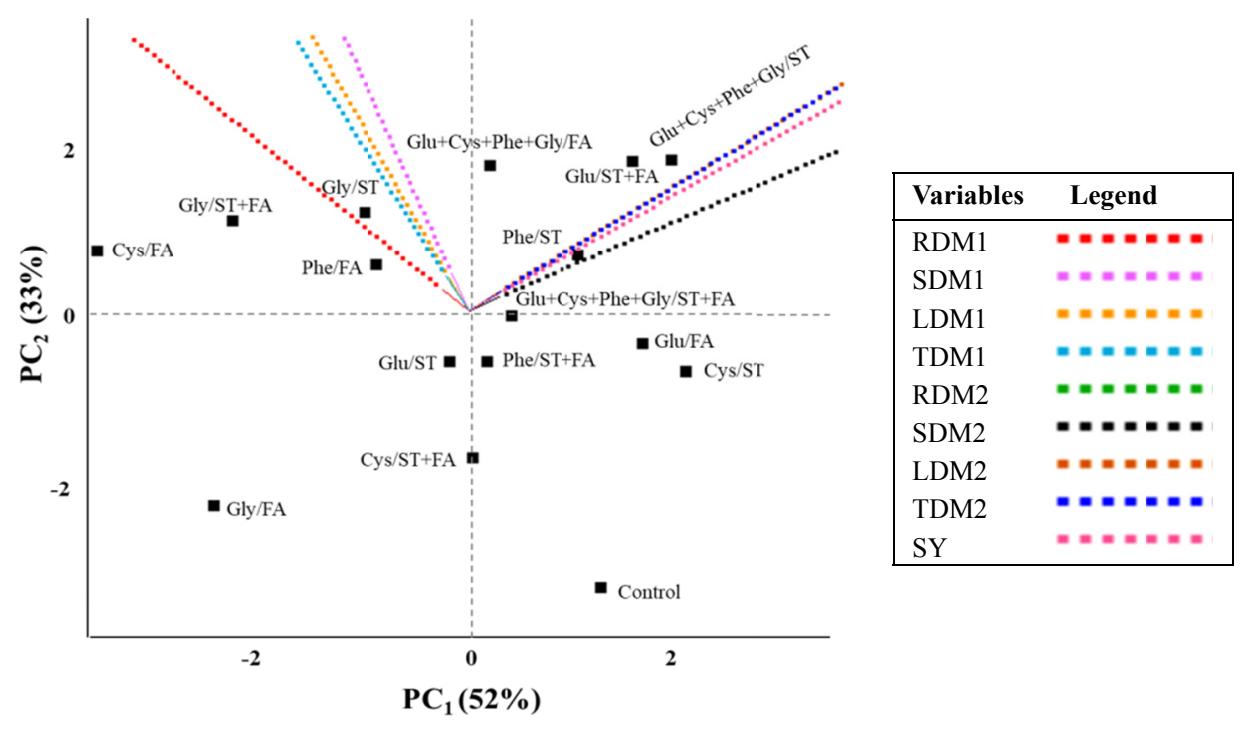

Figure 3. Byplot obtained from the analysis of main components of the results of use of glutamate (Glu), cysteine (Cys), phenylalanine (Phe), glycine (Gly) and all these amino acids in association (Glu + Cys + Phe +

Gly), as function of seed treatment (ST) and foliar application (FA), on the soybean root dry mass at $\mathrm{V}_{6}$-six nodes on the main stem, 20 DAS (RDM1) and at $\mathrm{R}_{7}$ stage-beginning maturity, 100 DAS (RDM2), stem dry mass at $\mathrm{V}_{6}$ (SDM1) ) and at $\mathrm{R}_{7}$ stage (SDM2), leaf dry mass at $\mathrm{V}_{6}$ (LDM1) and at $\mathrm{R}_{7}$ stage (LDM2), total dry mass at $\mathrm{V}_{6}$ (TDM1) and at $\mathrm{R}_{7}$ stage (TDM2) and soybean seed yield (SY). Greenhouse experiment, Season 2014/2015

\subsection{Field Experiment}

At the $\mathrm{V}_{6}$ stage, the use of glycine as ST promoted the increase of stem and total dry mass, representing 48 and $32 \%$ increase, respectively, in comparison to the control (Figures 4A and 4C). The leaf dry mass increased with the use of glutamate as ST (Figure 4B).

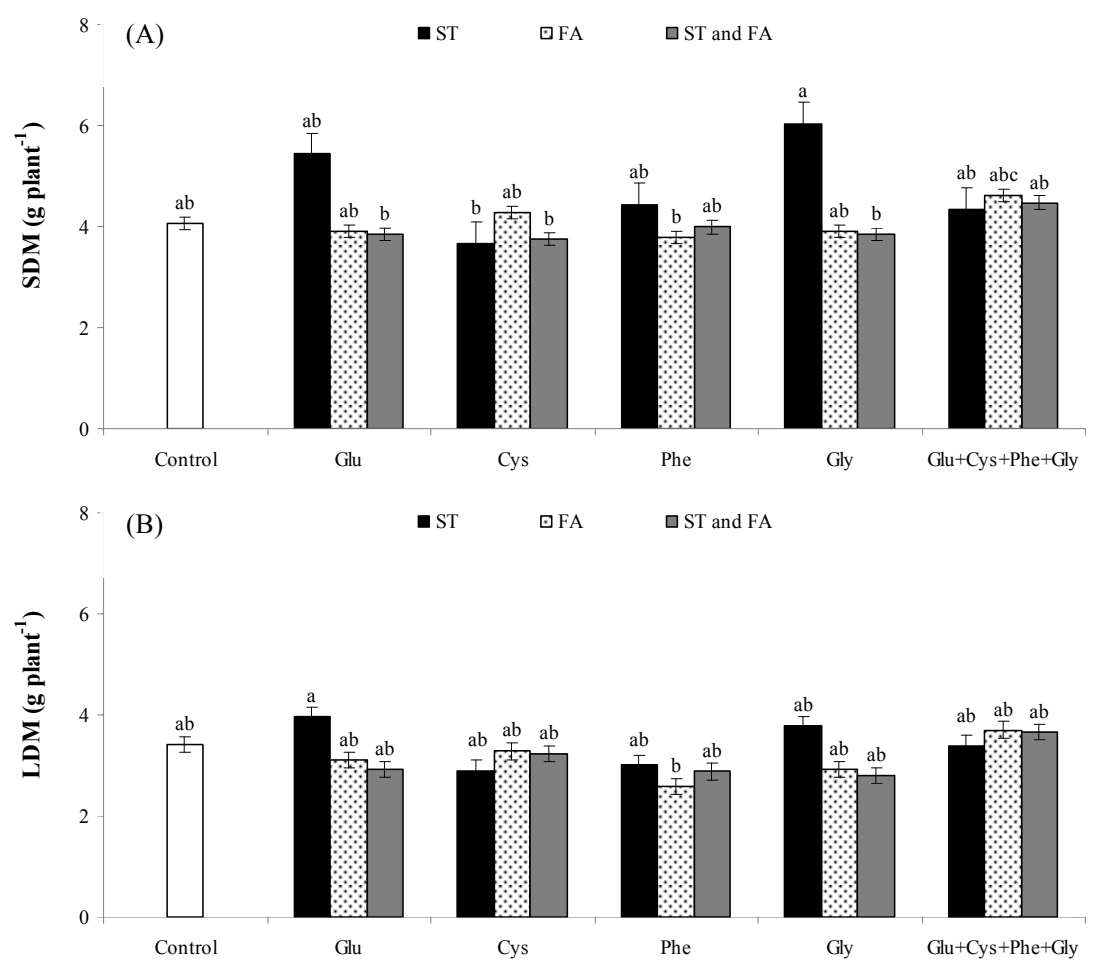




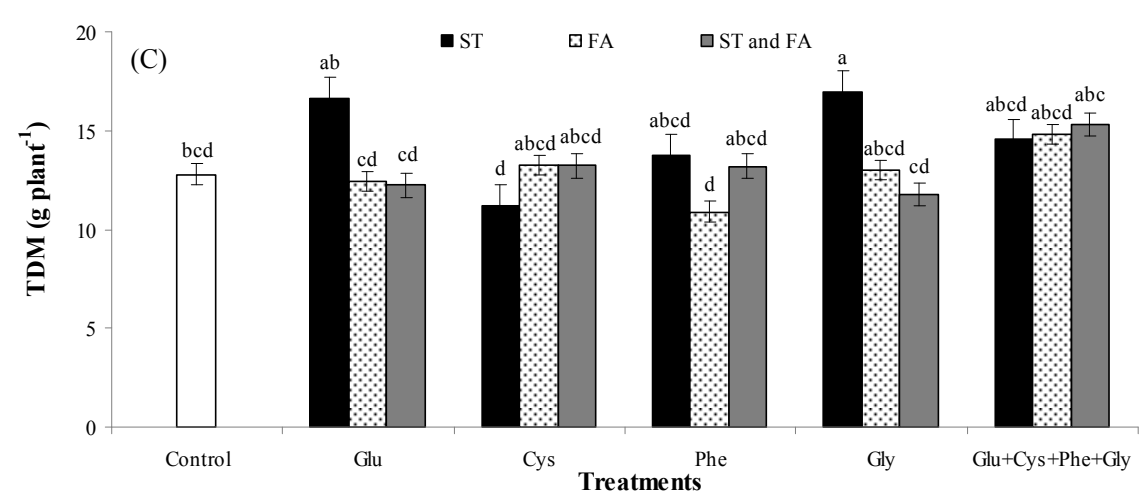

Figure 4. Effects of use of glutamate (Glu), cysteine (Cys), phenylalanine (Phe), glycine (Gly) and all these amino acids in association (Glu + Cys + Phe + Gly), as function of seed treatment (ST) and foliar application (FA), on the stem dry mass (SDM, A), leaf dry mass (LDM, B) and total dry mass (TDM, C) at $\mathrm{V}_{6}$ stage. Field experiment, Season 2014/2015. Means followed by the same letters do not differ significantly from each other, using the Duncan test $(\mathrm{p}>0.05)$

On the other hand, at the $\mathrm{R}_{8}$ stage, the use of phenylalanine as $\mathrm{ST}$ provided the best results for stem, leaf, pod and the total dry mass, representing increases of up to $152 \%$ compared to the control (Figures 5A, 5B, 5C and 5D). These increases may have favored the higher seed yield of the plants submitted to this treatment, with had a seed yield $46 \%$ higher than the control (Figure 5E).

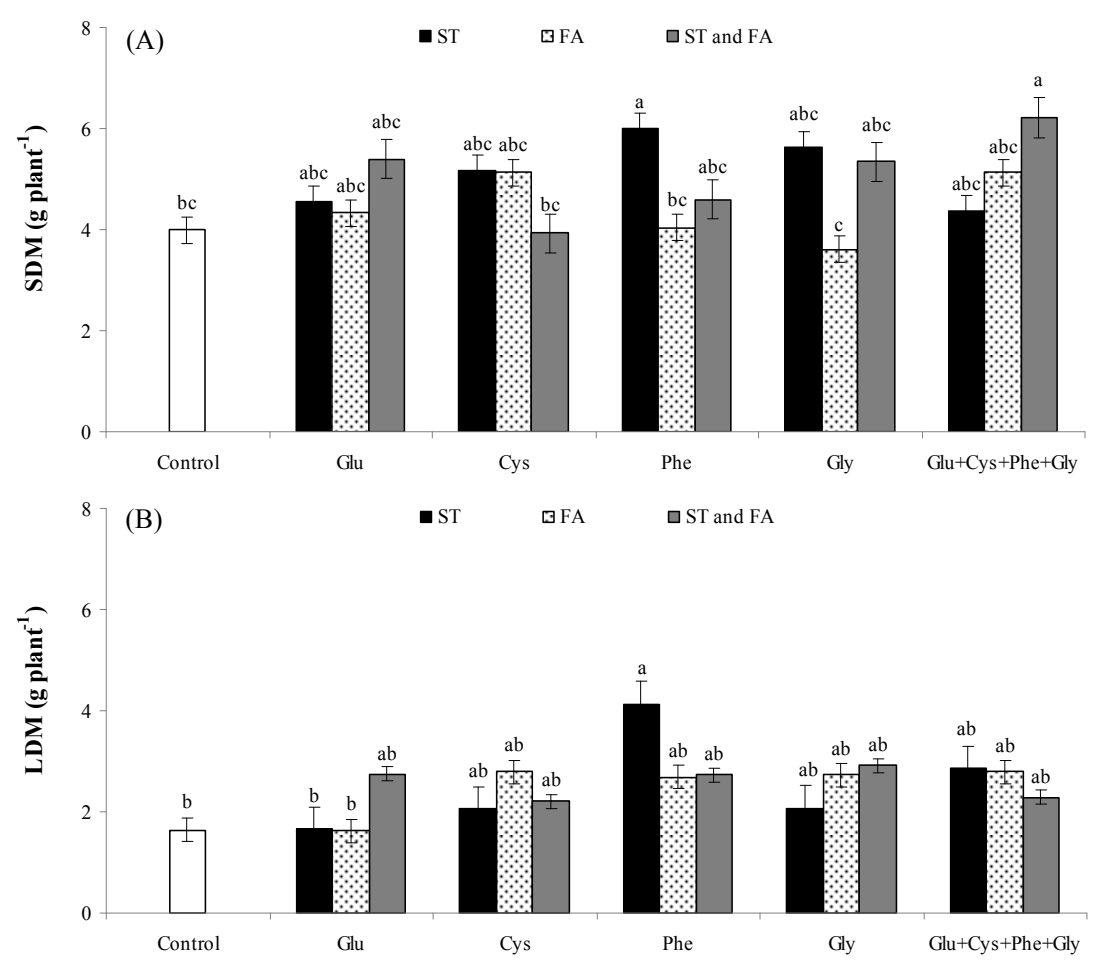



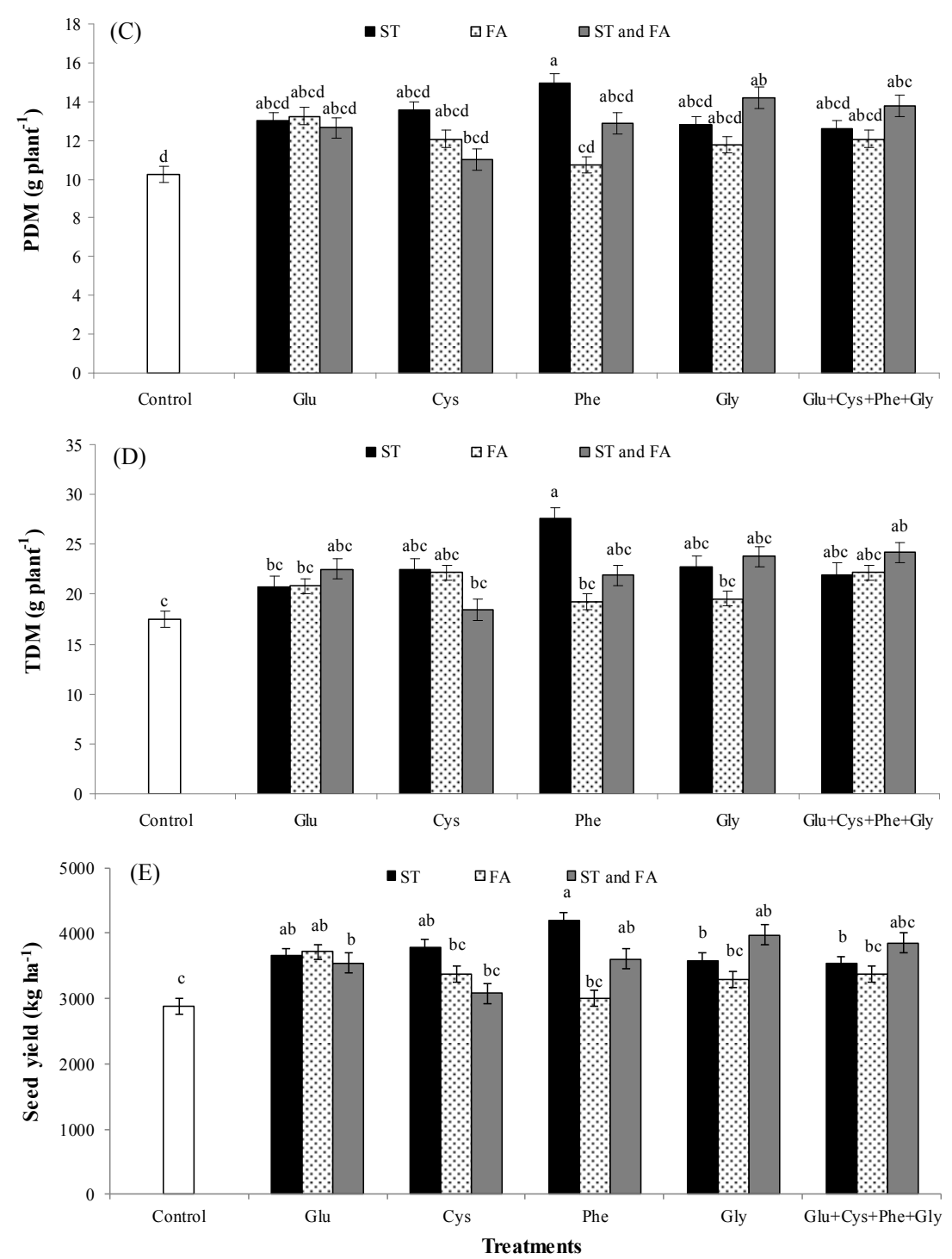

Figure 5. Effects of use of glutamate (Glu), cysteine (Cys), phenylalanine (Phe), glycine (Gly) and all these amino acids in association (Glu + Cys + Phe + Gly), as function of seed treatment (ST) and foliar application (FA), on the stem dry mass (SDM, A), leaf dry mass (LDM, B), pod dry mass (PDM, C) and total dry mass (TDM, D) at $\mathrm{R}_{8}$ stage, and soybean seed yield (E). Field experiment, Season 2014/2015. Means followed by the same letters do not differ significantly from each other, using the Duncan test $(p>0.05)$

The variables dry mass and seed yield were more important in the analyzes and were represented by PC1 and PC2 (Figure 6). The seed yield showed a higher correlation with total, stem and leaf dry mass, and the treatment with phenylalanine was correlated with the increase in seed yield. 


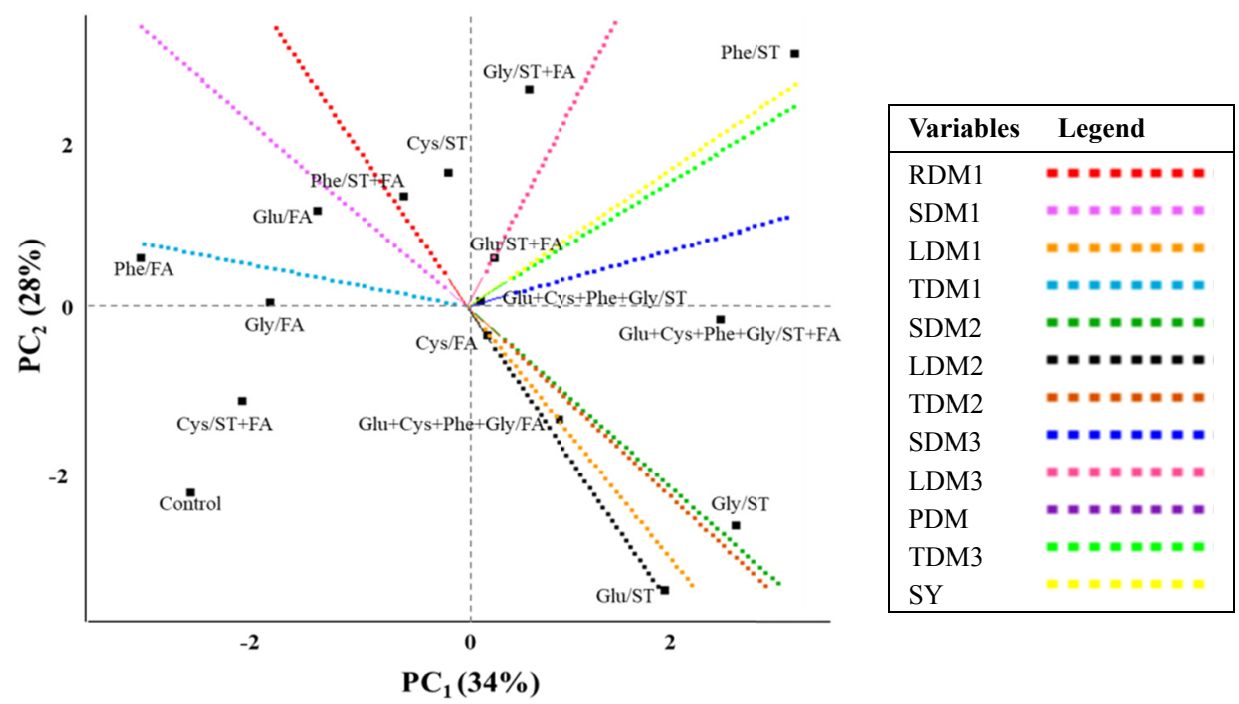

Figure 6. Byplot obtained from the analysis of main components of the results of use of glutamate (Glu), cysteine (Cys), phenylalanine (Phe), glycine (Gly) and all these amino acids in association (Glu $+\mathrm{Cys}+\mathrm{Phe}+$ Gly), as function of seed treatment (ST) and foliar application (FA), on the soybean stem dry mass at $\mathrm{V}_{6}$-six nodes on the main stem, 20 DAS (SDM1) and at $\mathrm{R}_{8}$ stage-full maturity, 110 DAS (SDM2), leaf dry mass at $\mathrm{V}_{6}$

(LDM1) and at $\mathrm{R}_{8}$ stage (LDM2), total dry mass at $\mathrm{V}_{6}$ (TDM1) and at $\mathrm{R}_{8}$ stage (TDM2), pod dry mass at $\mathrm{R}_{8}$ stage (PDM2) and soybean seed yield (SY). Field experiment, Season 2014/2015

Determination of leaf element accumulation at $\mathrm{V}_{6}$ stage shows a better effect of amino acids when applied in both modes ST and FA. The application of glutamate in these two modes of application increased the contents of $\mathrm{K}, \mathrm{Mn}, \mathrm{Fe}, \mathrm{Cu}$ and $\mathrm{Zn}$ in leaves, when compared to the control (Table 3).

The use of glicyne increased concentration of $\mathrm{P}$ and S. For all treatments the total nitrogen in leaves increased in relation to the control. On the other hand, the foliar application of glycine reduced the concentration of several elements in leaves, such as $\mathrm{P}, \mathrm{K}, \mathrm{S}$ and $\mathrm{Cu}$.

Table 3. Effects of use of glutamate (Glu), cysteine (Cys), phenylalanine (Phe), glycine (Gly) and all these amino acids in association (Glu + Cys + Phe + Gly), as function of seed treatment (ST) and foliar application (FA), on the element concentration in leaves at V6 stage. Field experiment, Season 2014/2015.

\begin{tabular}{|c|c|c|c|c|c|c|c|c|c|c|c|}
\hline \multirow{2}{*}{ Treatments } & \multirow{2}{*}{$\begin{array}{l}\text { Moment of } \\
\text { application }\end{array}$} & \multicolumn{10}{|c|}{ Element } \\
\hline & & $\mathbf{N}$ & $\mathbf{P}$ & $\mathbf{K}$ & Mg & $\mathbf{S}$ & $\mathbf{C a}$ & Mn & $\mathbf{F e}$ & $\mathbf{C u}$ & $\mathbf{Z n}$ \\
\hline & & \multicolumn{6}{|c|}{ 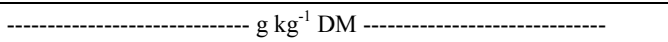 } & \multicolumn{4}{|c|}{ 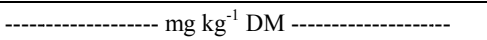 } \\
\hline Control & - & $32.0 \mathrm{~b}$ & $2.7 \mathrm{abc}$ & $15.3 \mathrm{abc}$ & $2.6 \mathrm{bc}$ & $1.77 \mathrm{abc}$ & $8.9 \mathrm{ab}$ & $94.3 \mathrm{ab}$ & $240.3 \mathrm{abc}$ & $45.6 \mathrm{ab}$ & $33.4 \mathrm{abc}$ \\
\hline Glutamate (Glu) & & $41.2 \mathrm{a}$ & 2.4 abcdef & 14.9 abcd & $3.0 \mathrm{a}$ & $1.54 \mathrm{de}$ & $8.7 \mathrm{abc}$ & $88.9 \mathrm{ab}$ & $190.1 \mathrm{c}$ & $38.7 \mathrm{cdef}$ & 30.0 abcde \\
\hline Cysteine (Cys) & & $41.2 \mathrm{a}$ & 2.5 abcde & $14.1 \mathrm{~cd}$ & $2.7 \mathrm{bc}$ & 1.60 bcde & $7.7 \mathrm{~d}$ & $76.1 \mathrm{~b}$ & $150.7 \mathrm{c}$ & $38.3 \mathrm{def}$ & 27.7 cde \\
\hline Phenylalanine (Phe) & ST & $40.8 \mathrm{a}$ & $2.3 \mathrm{cdef}$ & 14.6 abcd & $2.7 \mathrm{bc}$ & 1.72 abcde & $8.5 \mathrm{abcd}$ & $100.0 \mathrm{ab}$ & $192.6 \mathrm{bc}$ & $44.3 \mathrm{abcd}$ & $34.6 \mathrm{ab}$ \\
\hline Glycine (Gly) & & $39.5 \mathrm{a}$ & 2.7 abcd & $14.6 \mathrm{abcd}$ & $2.8 \mathrm{abc}$ & $1.74 \mathrm{abcd}$ & $8.1 \mathrm{bcd}$ & $81.6 \mathrm{ab}$ & $213.7 \mathrm{abc}$ & $36.3 \mathrm{ef}$ & 29.4 bcde \\
\hline Glu + Cys + Phe + Gly & & $41.9 \mathrm{a}$ & 2.5 abcde & $14.6 \mathrm{abcd}$ & $2.7 \mathrm{bc}$ & 1.68 abcde & $8.2 \mathrm{bcd}$ & $88.8 \mathrm{ab}$ & $195.8 \mathrm{bc}$ & 39.7 bcdef & $25.4 \mathrm{e}$ \\
\hline Glu & & $40.1 \mathrm{a}$ & $2.7 \mathrm{ab}$ & $15.2 \mathrm{abc}$ & $2.9 \mathrm{ab}$ & 1.69 abcde & $9.0 \mathrm{ab}$ & $95.1 \mathrm{ab}$ & $184.2 \mathrm{c}$ & $38.2 \mathrm{def}$ & $32.3 \mathrm{abcd}$ \\
\hline Cys & & $41.0 \mathrm{a}$ & $2.3 \mathrm{cdef}$ & $15.2 \mathrm{abc}$ & $2.5 \mathrm{c}$ & 1.55 cde & $9.2 \mathrm{a}$ & $102.5 \mathrm{a}$ & $236.2 \mathrm{abc}$ & 42.3 abcde & $31.4 \mathrm{abcd}$ \\
\hline Phe & FA & $42.3 \mathrm{a}$ & 2.4 bcdef & $14.1 \mathrm{~cd}$ & $2.5 \mathrm{c}$ & $1.49 \mathrm{e}$ & $7.8 \mathrm{~cd}$ & $81.7 \mathrm{ab}$ & $178.6 \mathrm{c}$ & 41.6 abcdef & $31.5 \mathrm{abcd}$ \\
\hline Gly & & $40.2 \mathrm{a}$ & $2.1 \mathrm{f}$ & $13.8 \mathrm{~d}$ & $2.7 \mathrm{bc}$ & $1.50 \mathrm{e}$ & $8.8 \mathrm{ab}$ & $82.3 \mathrm{ab}$ & $291.2 \mathrm{ab}$ & $35.7 \mathrm{f}$ & $27.2 \mathrm{de}$ \\
\hline Glu+Cys+Phe+Gly & & $38.7 \mathrm{a}$ & $2.2 \mathrm{ef}$ & $14.1 \mathrm{~cd}$ & $2.7 \mathrm{abc}$ & 1.61 abcde & 8.6 abcd & $92.5 \mathrm{ab}$ & $216.9 \mathrm{abc}$ & $35.8 \mathrm{f}$ & $26.6 \mathrm{de}$ \\
\hline Glu & & $42.1 \mathrm{a}$ & 2.5 abcde & $15.7 \mathrm{a}$ & $2.8 \mathrm{abc}$ & 1.66 abcde & 8.6 abcd & $104.0 \mathrm{a}$ & $309.2 \mathrm{a}$ & $47.9 \mathrm{a}$ & $35.5 \mathrm{a}$ \\
\hline Cys & & $42.2 \mathrm{a}$ & 2.5 abcde & $15.5 \mathrm{ab}$ & $2.8 \mathrm{abc}$ & $1.79 \mathrm{ab}$ & $8.9 \mathrm{ab}$ & $86.0 \mathrm{ab}$ & $215.9 \mathrm{abc}$ & $45.0 \mathrm{abc}$ & 30.4 abcde \\
\hline Phe & Both ST + FA & $42.1 \mathrm{a}$ & $2.6 \mathrm{abcd}$ & 14.7 abcd & $2.6 \mathrm{bc}$ & 1.67 abcde & $9.2 \mathrm{a}$ & $89.5 \mathrm{ab}$ & $220.6 \mathrm{abc}$ & 40.3 bcdef & $32.3 \mathrm{abcd}$ \\
\hline Gly & & $41.7 \mathrm{a}$ & $2.7 \mathrm{a}$ & $15.3 \mathrm{abc}$ & $2.7 \mathrm{bc}$ & $1.8 \mathrm{a}$ & $8.1 \mathrm{bcd}$ & $92.3 \mathrm{ab}$ & $227.4 \mathrm{abc}$ & 41.9 abcdef & 30.3 abcde \\
\hline Glu + Cys + Phe + Gly & & $45.2 \mathrm{a}$ & 2.5 abcde & $14.4 \mathrm{bcd}$ & $2.5 \mathrm{c}$ & 1.60 bcde & 8.6 abcd & $103.2 \mathrm{a}$ & $178.73 \mathrm{c}$ & 42.1 abcdef & $34.7 \mathrm{ab}$ \\
\hline
\end{tabular}

Note. Means followed by the same letters in the column do not differ significantly from each other, using the Duncan test at 5\% significance. 


\section{Discussion}

Different responses regarding the application of amino acids in plants were observed in the two experiments. The main effect of these molecules is the signaling of plants (Price et al., 2012; Forde \& Roberts, 2014; Santi et al., 2017), and this characteristic is influenced according to the need of the plant at a given moment. Therefore, different environmental conditions may affect different physiological parameters of plants. In the greenhouse experiment the use of cysteine in ST and glycine in both modes ST + FA increased the root dry mass (Fig. 1A). Nagao et al. (2005) observed that the foliar application of proline + lysine at the rates of 80 and $40 \mathrm{mg} \mathrm{L}^{-1}$ resulted in the addition of the total fresh mass of Lolium multiflorum. The benefits of increased dry matter mass on seed yield were observed in this experiment, where it was shown that the accumulation of dry matter mass showed a high and positive correlation with seed yield (Figure 3). The set of amino acids were more effective when applied in both ST + FA modes, which increased LDM and TDM at $\mathrm{R}_{7}$ stage (Figure 2).

The set of amino acids was more effective when applied in both ST + FA modes, which increased LDM and $\mathrm{TDM}$ at the $\mathrm{R}_{7}$ stage (Figure 2).

Glycine, cysteine and glutamate proteins act on plant signaling pathways and can increase oxidative and nitrogen metabolism (Teixeira et al., 2017; Teixeira et al., 2018). However, the various benefits provided by these amino acids were not sufficient to increase the final yield of the plants in the greenhouse experiment.

In the field experiment the best responses in the dry mass variables occurred with the application of amino acids in the seed treatment. Glycine, glutamate and phenylalanine were the most effective amino acids. Glutamate increased LDM at the $\mathrm{V}_{6}$ stage (Figure $4 \mathrm{~B}$ ). The increase of leaf area is fundamental for plants as it increases the photosynthetic area, which leads to greater photoassimilate production, which can be used during the grain filling phase, and in this way leading to a productivity increment (Board \& Modali, 2005).

The set of amino acids in both modes of application increased the TDM at the V8 stage, a characteristic that also had repercussions on the seed yield increment. These results corroborate Soares et al. (2016), using applications of different amino acids (glutamate, cysteine, glycine, arginine and methionine, at the rates of 31, 30, 34, 42 and $37 \mathrm{mg} \mathrm{kg}^{-1}$ of seeds, respectively), verified increase in soybean seeds yield cultivated in the field. Sadak et al., (2014) developed experiment using foliar application of amino acid mixtures of the commercial product Vicia faba consisting of aspartic acid, serine, glutamate, proline, lysine, methionine, isoleucine, leucine, tyrosine, phenylalanine, histidine and arginine. At the dose of $1500 \mathrm{mg} \mathrm{L}^{-1}$, it promoted an increase in plant dry matter mass, as well as increased carbohydrate, polysaccharide content and plant research. The most significant effect was provided by the application of phenylalanine in ST, which increased SDM, LDM, PDM and TDM.

The higher dry mass production leads to the greater amount of energy available for the grain filling stage, thus leading to increased productivity (Board \& Modale, 2005). The phenylalanine also acts on important routes of the secondary metabolism, such as the production of flavonoids and lignins, important for plant resistance (Taiz \& Zeiger, 2013, Teixeira et al., 2017). In addition, the phenylalanine can act as activated GRLs (Weiland et al., 2015), which act on signaling for changes in root architecture, protection against stress (Weiland et al., 2015, Teixeira et al., 2017) and carbon balance/photosynthesis (Weiland et al., 2015).

Regarding the concentration of element in the plant, the effect of the amino acids on the nutritional status was better evidenced when the application was performed in both ST + FA modes of application. The use of glutamate increased the concentration of $\mathrm{K}$ and micronutrients in the leaves (Table 3). $\mathrm{K}$ acts on ATPase activation due to its effect on the load balance. In this way, ATP synthesis is directly linked to the availability of potassium. Therefore, the transport of energy from the source to the drain during grain filling is dependent on potassium, which may explain the observed increase in productivity (Marschner, 2012). Increases in the Mn, Fe, $\mathrm{Cu}$ and $\mathrm{Zn}$ content are also important because, in addition to other functions, these elements act in the path of oxidative metabolism, forming or activating enzymes that eliminate toxic substances produced under stress conditions. In addition, we have already shown that the application of glutamate reduces lipid peroxidation in soybean plants (Teixeira et al., 2017). The application of Glycine in both ST + FA modes of application favored the accumulation of $\mathrm{P}$ and $\mathrm{S}$ in the leaves, in this case, $\mathrm{P}$ is also an extremely important element for grain filling, since it is part of the ATP formation, thus providing energy for this process. In addition, the entry of inorganic phosphorus $(\mathrm{Pi})$ into the chloroplast stroma is required to exit the trioses, which follow for the synthesis of sucrose, which is then transported to drain organs (Buchanan et al., 2000). Therefore, all these characteristics may explain the increase in seed yield from the application of these two amino acids.

The use of the amino acids glutamate, glycine, cysteine and phenylalanine increases plant dry mass and seed yield, especially when applied as seed treatment, with increments of up to $46 \%$ in seed yield with the use of 
phenylalanine. In relation to foliar concentration of elements, the most effective application is in both modes of application (ST and FA), mainly with glutamate and glycine.

It is suggested that more works are developed with plants of different cultivars and growth habits, in order to evaluate the effect of amino acids in these situations.

\section{References}

Board, J. E., \& Modali, H. (2005). Dry matter accumulation predictors for optimal yield in soybean. Crop Science, 45, 1790-1799. https://doi.org/10.2135/cropsci2004.0602

Borek, S., Galor, A., \& Paluch, E. (2013). Asparagine enhances starch accumulation in developing and germinating lupin seeds. Journal of Plant Growth Regulation, 32, 471-782. https://doi.org/10.1007/ s00344-012-9313-5

Buchanan, B. B., Gruissem, W., \& Jones, R. L. (2000). Biochemistry and Molecular Biology of Plants. Rockville, MD: American Society of Plant physiologists.

DeLille, J. M., Sehnke, P. C., \& Ferl, R. J. (2011). The Arabdopsis 14-3-3 family of signaling regulators. Plant Physiology, 126, 35-38. https://doi.org/10.1104/pp.126.1.35

Forde, B. G., \& Roberts, M. R. (2014). Glutamate receptor-like channels in plants: a role as amino acid sensors in plant defense? F1000Prime Rep., 37, 6-37. https://doi.org/10.12703/P6-37

Hildebrandt, T. M., Nunes Nesi, A., Araújo, W. L., \& Braun, H. P. (2015). Amino Acid Catabolism in Plants. Molecular Plant, 8, 1563-1579. https://doi.org/10.1016/j.molp.2015.09.005

Hirner, A., Ladwig, F., Stransky, H., Okumoto, S., Keinath, M., Harms, A., ... Koch, W. (2006). Arabidopsis LHT1 is a high-affinity transporter for cellular amino acid uptake in both root epidermis and leaf mesophyll. Plant Cell, 18, 1931-1946. https://doi.org/10.1105/tpc.106.041012

Johnson, C. M., Stout, P. R. Broyer, T. C., \& Carlton, A. B. (1957). Comparative chlorine requirement of different plant species. Plant and Soil, 8, 337-353.

Lee, Y. H., Foster, J., Chen, J., Voll, L. M., Weber, A. P. M., \& Tegeder, M. (2007). AAP1 transports uncharged amino acids into roots of Arabidopsis. The Plant Journal, 50, 305-319. https://doi.org/10.1111/ j.1365-313X.2007.03045.x

Maeda, H., \& Dudareva, N. (2012). The shikimate pathway and aromatic amino acids biosynthesis in plants. Annual Review of Plant Biology, 63, 73-105. https://doi.org/10.1146/annurev-arplant-042811-105439

Marschner, H. (2012). Mineral nutrition of higher plants (2nd ed., p. 889). Academic Press.

Miller, A. J., Fan, X., Shen, Q., \& Smith, S. J. (2007). Amino acids and nitrate as signals for the regulation of nitrogen acquisition. Journal of Experimental Botany, 59, 111-119. https://doi.org/10.1093/jxb/erm208

Nagao, K., Takeuchi, M., Miyazawa, Y., Sato, H., Yokota, H. O., \& Kita, K. (2005). Foliar application of fertilizer based on proline and inosine stimulates the second flush growth of Italian ryegrass (Lolium multiflorum Lam.). Grass and Forage Science, 51, 269-270. https://doi.org/10.1111/j.1744-697X.2005. 00034.x

Price, M. B., Jelesko, J., \& Okumoto, S. (2012). Glutamate receptor homologs in plants: functions and evolutionary origins. Frontiers in Plant Science, 3, 235. https://doi.org/10.3389/fpls.2012.00235

Sadak, M. S. H., Abdelhamid, M. T., \& Schmidhalter, U. (2014). Effect of foliar application of amino acids on plant yield and some physiological parameters in bean plants irrigated with seawater. Acta Biológica Colombiana, 20, 141-152. http://dx.doi.org/10.15446/abc.v20n1.42865

Santi, C., Zamboni, A., Varanini, Z., \& Pandolfini, T. (2017). Growth stimulatory effects and genome-wide transcriptional changes produced by protein hydrolysates in maize seedlings. Frontiers in Plant Science, 8. https://doi.org/10.3389/fpls.2017.00433

SAS Institute. (2011). SAS/STAT Statistical Analysis System Manual (v. 9.3). SAS Institute, Cary.

Soares, L. H., Dourado-Neto, D., Fagan, E. B., Teixeira, W. F., Reis, M. R. dos, \& Reichardt, K. (2016). Soybean seed treatment with micronutrients, hormones and amino acids on physiological characteristics of plants. African Journal of Agricultural Research, 35(11), 3314-3319. https://doi.org/10.5897/AJAR2016.11229

Taiz, L., \& Zeiger, E. (2013). Plant physiology (p. 782). Sunderland: Sinauer Associates. 
Teixeira, W. F., Fagan, E. B., Soares, L. H., Soares, J. N., Reichardt, K., \& Dourado Neto, D. (2018). Seed and foliar application of amino acids improve variables of nitrogen metabolism and productivity in soybean crop. Frontiers in Plant Science, 9(1). https://doi.org/10.3389/fpls.2018.00396

Teixeira, W. F., Fagan, E. B., Soares, L. H., Umburanas, R. C., Reichardt, K., \& Dourado Neto, D. (2017). Foliar and seed application of amino acids affects the antioxidant metabolism of the soybean crop. Frontiers in Plant Science, 8, 327. https://doi.org/10.3389/fpls.2017.00327

Walch-Liu, P., \& Forde, B. G. (2007). L-Glutamate as a Novel Modifier of Root Growth and Branching. What's the Sensor? Plant Signaling \& Behavior, 2(4), 284-286. https://doi:10.1093/pcp/pcj075

Weiland, M., Mancuso, S., \& Baluska, F. (2015). Signalling via glutamate and GLRs in Arabidopsis thaliana. Functional Plant Biology, 23, 1-25. https://doi.org/10.1071/FP15109

Zhao, Y. (2010). Auxin biosynthesis and its role in plant development. Annual Review of Plant Biology, 61, 49-64. https://doi.org/10.1146/annurev-arplant-042809-112308

\section{Copyrights}

Copyright for this article is retained by the author(s), with first publication rights granted to the journal.

This is an open-access article distributed under the terms and conditions of the Creative Commons Attribution license (http://creativecommons.org/licenses/by/4.0/). 